\title{
Dietary factors influencing the digestion of starch in the rumen and small and large intestine of early weaned lambs
}

\author{
BY E. R. ØRSKOV, C. FRASER AND R. N. B. KAY \\ Rowett Research Institute, Bucksburn, Aberdeen, $A B{ }_{2}{ }_{9} S B$
}

(Received 20 May 1968-Accepted 24 October 1968)

\begin{abstract}
1. Lambs fitted with cannulas in the abomasum, terminal ileum and caecum were used to study the digestion of starch and dry matter when rations with high starch content were given. Polyethylene glycol was used as an indigestible reference substance.

2. In Expt $I$ reduction in level of feeding from an estimated ad lib. intake to $70 \%$ of this level reduced the amount of dietary starch escaping fermentation in the rumen from 6.8 to $4.4 \%$ of intake on a barley diet and from 12.8 to $7.7 \%$ on a diet consisting of $40 \%$ dried grass and $60 \%$ barley. Inclusion of $40 \%$ chopped dried grass in the diet increased the amount of dietary starch escaping fermentation in the rumen. There appeared to be a linear relationship between the concentrations of starch in abomasal and ileal dry matter, indicating a limited capacity for starch digestion in the small intestine.

3. In Expt 2 a barley diet was compared with diets based on flaked maize, ground maize or cracked maize. With these diets the percentage of dietary starch escaping fermentation in the rumen was respectively $6 \cdot 2,5 \cdot 4,12 \cdot 1$ and $14 \cdot 2$, showing that more starch escapes fermentation with uncooked maize diets than with barley diets.

4. The molar proportions of volatile fatty acids produced by fermentation in the caecum were apparently influenced by the amount of starch passing to the intestines. The highest proportion of acetic acid $(78 \%$ ) was associated with $4.5 \%$ of starch in abomasal dry matter, and the lowest proportion $(57 \%$ ) was associated with $20.1 \%$ of starch in abomasal dry matter.

5. The possible relationships between the extent of fermentation in the rumen and energy and nitrogen metabolism are discussed.
\end{abstract}

It has generally been assumed that in ruminants only small quantities of digestible carbohydrate escape fermentation in the rumen and so remain available for absorption in the lower alimentary tract. The work of Heald (195I) and of Weller \& Gray (1954) showed that only negligible amounts of starch or reducing sugars entered the abomasum. Recently, however, Karr, Little \& Mitchell (r966) with steers, and Wright, Grainger \& Marco (1966) and Tucker, Mitchell \& Little (1968), with sheep, found that when ground maize was given substantial quantities of starch may escape fermentation in the rumen. Tucker et al. (1968) showed this to depend on level of intake, and noted quantities of up to $35 \%$ of dietary starch passing to the abomasum and disappearing in the small and large intestines. Calculation of a fermentation balance for dairy cows (Ørskov, Flatt \& Moe, I968) also suggested that the extent of fermentation depended upon the level of intake and proportion of concentrate in the diet. On the other hand, MacRae \& Armstrong (1968) and Topps, Kay \& Goodall (1968), with mature sheep, found only small amounts of starch escaping fermentation when barley was given, and Topps, Kay, Goodall, Whitelaw \& Reid (1968) did not find an effect of level of intake on the starch escaping fermentation in steers.

The extent of fermentation of starch in the rumen largely determines how much starch remains available for digestion in the small intestine when concentrates are given and so might have important consequences as far as energy and nitrogen meta- 
bolism are concerned. The present work was undertaken to measure the amounts of starch (i.e. $\alpha$-linked glucose) passing to the small intestine and to the large intestine in fistulated lambs and to see how these amounts were affected by the nature of the concentrate diets and the amount consumed. The disappearance of the digesta along the tract was estimated with polyethylene glycol (PEG) as an indigestible marker. The use of PEG for such a purpose was developed by Hydén (1955), who showed excellent recoveries of this compound in digestive tract contents. This marker follows the liquid phase of the digesta as opposed to chromic oxide which follows the solid phase. To limit large fluctuations in the PEG concentration and to ensure complete ingestion, it was here incorporated into the concentrate pellets. A preliminary account of the first experiment has been published (Ørskov \& Fraser, 1968).

\section{EXPERIMENTAL}

\section{Expt I}

Animals. Eight Cheviot or Cheviot $\times$ Suffolk lambs were fitted with Ebonite cannulas in the fundus of the abomasum when $5^{-10}$ days old. The lambs were removed from their dams about $3 \mathrm{~h}$ before surgery. Anaesthesia was induced with trichloroethylene BP (Trilene, ICI), administered by use of a face mask, and maintained, after intubation of the trachea, with halothane-oxygen from a closed-circuit apparatus. At the same operation, or I-4 weeks later, a second (Perspex) cannula was inserted into four of these lambs. In two the cannula was placed in the terminal ileum, about $20 \mathrm{~cm}$ from the caecum, and in the other two it was placed in the caecum, opposite to the ileo-caecal junction.

All the cannulas had barrels about $4.5 \mathrm{~cm}$ long and $\mathrm{I} \cdot \mathrm{I} \mathrm{cm}$ internal diameter, and were closed by a combined cap and core which prevented digesta accumulating in the barrel between sampling times. The abomasal cannulas had a circular inner flange of $4 \mathrm{~cm}$ diameter. The intestinal cannulas had gutter-shaped inner flanges, about $4.5 \mathrm{~cm}$ in length and $\mathrm{I} \cdot \mathrm{I} \mathrm{cm}$ in diameter.

After recovery from the anaesthetic, the lambs were returned to their dams; they were welcomed affectionately and began to suckle immediately. There were no immediate postoperative difficulties. One lamb with a caecal cannula had to be killed 4 weeks after operation owing to prolapse of the caecum, and so was excluded from the experimental group of eight lambs. Another lamb, included in the experimental group, was killed I I weeks after operation, also because of prolapse of the caecum. Otherwise the animals remained healthy and had excellent appetites throughout the experiment.

During their first 5 weeks of life they suckled their dams and received concentrates ad lib. They were then abruptly weaned on to a concentrate ration (see treatment RB below) and were introduced to one of the dietary treatments of Expt I when they were about 6 weeks old and weighed about $\mathrm{I}_{5} \mathrm{~kg}$.

Treatments. Two levels of feeding were used, one close to maximum intake (ad lib.) and the other $70 \%$ of this (restricted). The $a d$ lib. level was computed from the $a d l i b$. intake of similar lambs during the period in which they increased their weight from 
I 5 to $40 \mathrm{~kg}$ and when they received a rolled barley ration. The equation which described this intake was $y=5-0.0353 \mathrm{~W}$, where $y$ is air-dry feed offered per day as $\%$ of live weight, and $W$ is live weight in $\mathrm{kg}$.

In treatment RB a concentrate consisting mainly of rolled barley was given at the two levels of intake; in treatment RBG a mixture of $60 \%$ of the rolled barley concentrate and $40 \%$ of dried grass was given at the two levels of intake; in treatment GB a concentrate consisting mainly of ground barley was given $a d l i b$. only; in treatment RBM a mixture of $72 \%$ of the rolled barley concentrate and $28 \%$ of maltose was given ad lib. only. All the rations were pelleted.

Composition and preparation of feeds. The ingredients of the concentrate in treatment RB were ( $\%$ by weight); rolled barley 80 , molassine meal 4 , soya-bean meal 7 , white fish meal 5 , minerals 2, sodium chloride I, and PEG I. In treatment GB the rolled barley was replaced by ground barley. The concentrate in treatment RBM contained rolled barley 50 , maltose 28 , soya-bean meal 9 ; the other ingredients were similar to those used in treatment RB. The minerals consisted of $75 \%$ dicalcium phosphate, $17.5 \%$ calcium carbonate and $7.5 \%$ magnesium oxide. In addition, the concentrate contained $6.5 \times 10^{6}$ i.u. vitamin $\mathrm{A} /$ ton and $\mathrm{I} \cdot 25 \times 10^{6}$ i.u. vitamin $\mathrm{D} /$ ton and trace minerals according to recommendations of the Agricultural Research Council (1965) except that no supplementary iron or copper was given.

Table I. Composition of diets (\% of dry matter)

$\begin{array}{lccc}\text { Diet } & \text { Starch* } & \text { Crude protein } & \text { Ether extract } \\ \text { (RB) } & 47 \cdot 6 & 16 \cdot 4 & 2 \cdot 0 \\ \text { f (GB) } & 48 \cdot 1 & 17 \cdot 0 & 2 \cdot 2 \\ & 49 \cdot 2 & 16 \cdot 6 & 0 \cdot 9 \\ (\mathrm{FM}) & 4 \cdot 1 & 14 \cdot 4 & -- \\ \text { (GM) } & 56 \cdot 0 & 14 \cdot 1 & 4 \cdot 1 \\ \text { * } & 54 \cdot 9 & 16 \cdot 3 & 3 \cdot 6 \\ & 52 \cdot 9 & 15 \cdot 1 & 3 \cdot 8 \\ & \text { Determined as } \alpha \text {-linked glucose. }\end{array}$

The composition of the diets can be seen in Table $\mathbf{I}$. Starch was estimated as $\alpha$-linked glucose by the method of MacRae $\&$ Armstrong (1968). The dried grass was of good quality, the acid detergent fibre of the dried grass being $26 \cdot 2$, determined by the method of Van Soest ( 1963 ), and the digestibility of ration RBG was not significantly different from that of ration RB.

Design. The design was that of four $4 \times 4$ latin squares where, for the first four periods, four lambs in turn received diets RB and RBG at the two levels of feeding (square I) and four received diets RB, RBG, GB and RBM in turn (square 2) during the next four periods. When this was completed the animals in square I were changed to square 2 and vice versa. The periods were II days.

Management of animals, sampling and analytical procedures. The animals were given their daily allowance of feed in two equal portions at $08.00 \mathrm{~h}$ and $20.00 \mathrm{~h}$. Uneaten feed, if any, was removed and recorded every day. Water was available at all times. 
To avoid consumption of bedding the animals were kept on wooden slats in individual pens. On the last day of each period samples were obtained of abomasal, ileal and caecal contents and of faeces taken from the rectum at 09.00, I I.00, I3.00, I5.00, 17.00 and $19.00 \mathrm{~h}$, and the live weights of the lambs were recorded. These samples were pooled and kept frozen until analysed for starch, PEG and dry matter. The $\mathrm{pH}$ of abomasal, ileal and caecal samples was determined by a Beckman glass electrode $\mathrm{pH}$ meter at each sampling time. About $25 \mathrm{ml}$ of digesta were taken from the abomasum at each sampling and $\mathrm{ro} \mathrm{ml}$ were added to the composite sample. Sometimes there was no digesta present at the site of the ileal cannulas so that most composite ileal samples contained only about three samples rather than the maximum of six.

The composite samples were freeze-dried and kept in desiccators before being analysed. PEG was estimated by the method of Hydén (1955) but with the modification of Smith (1958) as far as abomasal and ileal samples were concerned. Freeze-dried material $(\mathrm{Ig}$ ) was suspended in $\mathrm{I} 2 \mathrm{ml}$ of water and shaken thoroughly and then treated according to the methods referred to. Volatile fatty acids (VFA) were determined in $2.5 \mathrm{ml}$ caecal contents diluted with $2.5 \mathrm{ml}$ water and acidified with I $\mathrm{ml} \mathrm{of} 25 \%$ metaphosphoric acid. The VFA proportions were determined by gas-liquid chromatography with a Pye 104 flame-ionization detector.

\section{Expt 2}

Expt I showed that, though appreciable quantities of starch escaped rumen fermentation, the quantities were much smaller than those reported by Tucker $e t$ al. (1968) and Wright et al. (1966). It was therefore decided to conduct an experiment in which rolled barley was compared with flaked maize, ground maize or cracked maize, since the main difference between the dietary treatments was the use of barley in our work and maize in the American work.

Animals. Six of the lambs prepared for Expt I were used when they were approximately 6 months old and weighed about $37 \mathrm{~kg}$. They all had abomasal cannulas, two had ileal cannulas and one had a caecal cannula.

Treatments. Four treatments were used. Food was provided close to maximum intake (ad lib.) as calculated in Expt $\mathrm{I}$. Treatment RB was identical with treatment RB in Expt I. In treatments FM, GM and CM rolled barley was replaced by flaked maize, ground maize and cracked maize respectively.

Composition and preparation of feeds. The feeds were prepared as in Expt I and their composition is given in Table r. Management of the animals and sampling and analysis followed the procedures described for Expt I.

Design. The design was that of a $4 \times 4$ latin square, but in addition two more animals received the treatments in a randomized sequence. The length of periods and other conditions were similar to those in Expt I. 


\section{RESULTS}

\section{$\operatorname{Expt~\mathrm {I}}$}

The apparent digestibility of dry matter based on the ratio of PEG in feed to PEG in faecal dry matter, the growth rates of the lambs and the $\mathrm{pH}$ and dry-matter percentages of abomasal and ileal digesta are given in Table 2. There were no significant differences in the digestibilities of the diets. The lambs grew much more rapidly when fed $a d l i b$. than when restricted $(P<0.00 \mathrm{r})$ and tended to put on most weight with treatment RBM. No diurnal variation in the abomasal $\mathrm{pH}$ values was apparent. The dry-matter concentration in abomasal fluid was lower with treatment RBG than with treatments $\mathrm{RB}$ and $\mathrm{GB}(P<0.00 \mathrm{I})$. The $\mathrm{pH}$ and percentage dry matter in ileal fluid were based on observations on only two animals. Dry-matter concentration was highest with ration GB and tended to be lower with restricted feeding.

Since the feed intake varied during the experiment from 700 to $1400 \mathrm{~g} /$ day owing to the method of regulating intake, the results in Table 3 have been expressed on a

\section{Table 2. Expt I : digestibility of the diet, growth rates of lambs and the composition of abomasal and ileal digesta}

(Values are means with their standard errors for eight lambs (two for ileal digesta). Various rations consisting mainly of barley were given at an estimated ad lib. intake or restricted to $70 \%$ of estimated ad lib. intake)

Treatment

Rolled barley (RB)

Rolled barley (RB)

$60 \% \mathrm{RB}+40 \%$ dried grass (RBG)

$60 \% \mathrm{RB}+40 \%$ dried grass (RBG)

Ground barley (GB)

Rolled barley + maltose (RBM)

\begin{tabular}{|c|c|c|c|c|c|c|}
\hline & $\begin{array}{l}\text { Apparen } \\
\text { digesti- } \\
\text { bility of }\end{array}$ & & Abomas & digesta & & $\underbrace{\text { digesta }}$ \\
\hline $\begin{array}{c}\text { Feeding } \\
\text { level }\end{array}$ & $\begin{array}{c}\text { dry } \\
\text { matter } \\
(\%)\end{array}$ & $\begin{array}{c}\text { Live-weight } \\
\text { gain } \\
(\mathrm{kg} / \text { day })\end{array}$ & $\mathrm{pH}$ & $\begin{array}{c}\text { Dry } \\
\text { matter } \\
(\%)\end{array}$ & $\mathrm{pH}$ & $\begin{array}{c}\text { Dry } \\
\text { matter } \\
(\%)\end{array}$ \\
\hline Ad lib. & $75 \pm 2$ & $0.19 \pm 0.03$ & $2.9 \pm 0.03$ & $8 \cdot 3 \pm 0.3$ & $7 \cdot 5$ & I I $\cdot \mathbf{I}$ \\
\hline Restricted & $75 \pm 4$ & $0.04 \pm 0.04$ & $2.8 \pm 0.05$ & $8 \cdot 2 \pm 0.5$ & $7 \cdot 9$ & $8 \cdot 2$ \\
\hline Ad lib. & $73 \pm 4$ & $0.22 \pm 0.03$ & $2.9 \pm 0.03$ & $7 \cdot 1 \pm 0.3$ & $7 \cdot 8$ & 10.6 \\
\hline Restricted & $7^{6 \pm 2}$ & $0.08 \pm 0.04$ & $2 \cdot 8 \pm 0.05$ & $6.5 \pm 0.4$ & $7 \cdot 8$ & 9.7 \\
\hline $\begin{array}{l}\text { Ad lib. } \\
\text { Ad lib. }\end{array}$ & $\begin{array}{l}77 \pm 2 \\
76 \pm 4\end{array}$ & $\begin{array}{l}0.17 \pm 0.04 \\
0.27 \pm 0.04\end{array}$ & $\begin{array}{l}2.8 \pm 0.05 \\
2.8 \pm 0.05\end{array}$ & $\begin{array}{l}8.8 \pm 0.4 \\
6.9 \pm 0.4\end{array}$ & $\begin{array}{l}8 \cdot 1 \\
7 \cdot 8\end{array}$ & $\begin{array}{l}13.7 \\
10.2\end{array}$ \\
\hline
\end{tabular}

Table 3. Expt I: starch (determined as $\alpha$-linked glucose) reaching abomasal and ileal digesta and faeces, expressed as percentage of dry matter and percentage of intake of lambs

(Values are means for eight lambs (two for ileal digesta). Various rations consisting mainly of barley were given at an estimated $a d l i b$, intake or restricted to $70 \%$ of estimated $a d l i b$. intake)

Treatment

Rolled barley (RB)

Rolled barley (RB)

$60 \% \mathrm{RB}+40 \%$ dried grass (RBG)

$60 \% \mathrm{RB}+40 \%$ dried grass (RBG)

Ground barley (GB)

Rolled barley + maltose (RBM)
Starch in abomasal digesta

Percen-

tage of Percen-

$\begin{array}{ccc}\text { Feeding } & \begin{array}{c}\text { tage of } \\ \text { dry }\end{array} & \begin{array}{c}\text { tage of } \\ \text { level }\end{array} \\ \text { matter } & \text { intake }\end{array}$

Ad lib.

Restricted

Ad lib.

Restricted

Ad lib.

Ad lib.
$6.0 \pm 0.7 \quad 6.8 \pm 0.9$

$3 \cdot 6 \pm 1 \cdot I \quad 4 \cdot 4 \pm I \cdot 5$

$6 \cdot 2 \pm 0.7 \quad 12 \cdot 8 \pm 0.9$

$5 \cdot 1 \pm \mathrm{r} \cdot 0 \quad 7 \cdot 7 \pm \mathrm{I} \cdot 3$

$6 \cdot 1 \pm 0 \cdot 9 \quad 5 \cdot 5 \pm I \cdot 3$

$6.0 \pm 0.9 \quad 6.6 \pm 1.3$

\begin{tabular}{|c|c|}
\hline \multicolumn{2}{|c|}{$\begin{array}{l}\text { Starch in } \\
\text { ileal digesta }\end{array}$} \\
\hline $\begin{array}{l}\text { Percen- } \\
\text { tage of } \\
\text { dry } \\
\text { matter }\end{array}$ & $\begin{array}{c}\text { Percen- } \\
\text { tage of } \\
\text { intake }\end{array}$ \\
\hline $\begin{array}{l}3 \cdot 7 \\
2 \cdot 0\end{array}$ & $\begin{array}{l}I \cdot 4 \\
I \cdot 6\end{array}$ \\
\hline 3.9 & $5 \cdot \mathrm{I}$ \\
\hline $3 \cdot 6$ & $4 \cdot 3$ \\
\hline $2 \cdot 2$ & $\mathbf{I} \cdot 8$ \\
\hline$I \cdot 2$ & $I \cdot O$ \\
\hline
\end{tabular}

Starch in faeces

$\begin{array}{cc}\begin{array}{c}\text { Percen- } \\ \text { tage of } \\ \text { dry } \\ \text { matter }\end{array} & \begin{array}{c}\text { Percen- } \\ \text { tage of } \\ \text { intake }\end{array} \\ 0.6 \pm 0.08 & 0.2 \pm 0.06 \\ 0.6 \pm 0.08 & 0.3 \pm 0.06 \\ 0.4 \pm 0.08 & 0.3 \pm 0.06 \\ 0.4 \pm 0.08 & 0.3 \pm 0.06 \\ 0.4 \pm 0.08 & 0.2 \pm 0.06 \\ 0.7 \pm 0.08 & 0.3 \pm 0.06\end{array}$


percentage basis. There were no significant differences between periods, which indicated that the age of the lambs did not influence disappearance of starch in the rumen and small intestine. The proportions of dietary starch reaching the abomasum, small intestine and large intestine were calculated from the ratio between PEG in the diet and in the contents of each organ.

There was a significant increase with level of intake in the proportion of dietary starch (expressed as $\alpha$-linked glucose) passing the abomasum, both with diet RB $(P<0.05)$ and diet RBG $(P<0.001)$, and the over-all difference between the results for diets $\mathrm{RB}$ and $\mathrm{RBG}$ was significant $(P<0.00 \mathrm{I})$. For starch expressed as percentage of the dry matter in abomasal fluid, the difference between the results for the RB ad lib. and RB restricted treatments was also significant $(P<0.05$, single-tail test). The mean values for starch in ileal contents were based on observations on two animals and therefore were not suitable for statistical treatment. The values for diet RBG tended to be higher than those for any of the other diets. There were no effects of diet on the faecal starch content of faeces or on the proportion of dietary starch reaching the faeces.

The relation between the percentage of starch in abomasal dry matter and that in ileal dry matter was calculated for the two animals which were fitted both with abomasal and ileal cannulas. There was no significant difference between the results for the two animals, and a significant linear regression $(P<0.05)$ was fitted to the values $y=0.56 x-0.6$, where $y$ is the percentage of starch in ileal dry matter and $x$ the percentage of starch in abomasal dry matter.

\section{Expt 2}

Table 4 shows the proportions of dietary starch and dry matter reaching the abomasum and faeces in Expt 2. The abomasal values were transformed according to the angular transformation for calculation of standard errors in order to make the variability more homogeneous. The percentage of starch in the abomasal dry matter and the

Table 4. Expt 2: starch (determined as $\alpha$-linked glucose) reaching abomasal digesta and faeces expressed as percentage of dry matter and percentage of intake of lambs, and the dietary dry matter apparently reaching the abomasum and the faeces

(Values are means for six lambs)

\begin{tabular}{|c|c|c|c|c|c|c|}
\hline \multirow[b]{2}{*}{ Treatment } & $\begin{array}{r}\text { Starch in } \\
\text { dige }\end{array}$ & $\begin{array}{l}\text { abomasal } \\
\text { esta }\end{array}$ & Starch & in faeces & \multicolumn{2}{|c|}{$\begin{array}{c}\text { Dry matter } \\
\text { as percentage } \\
\text { of dietary intake }\end{array}$} \\
\hline & $\begin{array}{l}\text { Percentage } \\
\text { of dry mattex }\end{array}$ & $\begin{array}{l}\text { Percentage } \\
x \text { of intake }\end{array}$ & $\begin{array}{l}\text { Percentage } \\
\text { of dry matt }\end{array}$ & $\begin{array}{l}\text { Percentage } \\
\text { er of intake }\end{array}$ & $\begin{array}{c}\text { Reaching } \\
\text { abomasum }\end{array}$ & $\begin{array}{l}\text { Excreted } \\
\text { in faeces }\end{array}$ \\
\hline Rolled barley (RB) & $5 \cdot 9$ & $6 \cdot 2$ & I'5 & 0.8 & 53 & 27 \\
\hline Flaked maize (FM) & $7 \cdot 0$ & $5 \cdot 4$ & $x \cdot 8$ & 0.7 & 43 & $2 \pi$ \\
\hline Ground maize (GM) & 15.5 & $12-1$ & $\mathbf{I} \cdot \mathbf{I}$ & 0.5 & $4 I$ & 22 \\
\hline Cracked maize (CM) & 15.0 & 14.2 & $2 \cdot 0$ & 0.8 & 50 & 23 \\
\hline Standard error of means & $2 \cdot 80^{*}$ & $3 \cdot 25^{*}$ & 0.52 & 0.25 & 5.0 & $2 \cdot 0$ \\
\hline
\end{tabular}

* Calculated from the angular transformation of the percentages. 
Table 5. Expts I and 2: molar proportions of volatile fatty acids in the caecum of some lambs, together with the starch content of abomasal samples taken at the same time

(The first two rows give mean values for all rations and the last two rows the values when the proportion of acetic acid was highest and lowest (treatments RB (rolled barley) and CM (cracked maize) respectively))

\begin{tabular}{|c|c|c|c|c|c|c|c|c|}
\hline Expt & $\begin{array}{l}\text { No. of ( } \\
\text { observa- } \\
\text { tions }\end{array}$ & $\begin{array}{l}\text { Starch in } \\
\text { abomasal } \\
\text { fluid } \\
\text { (percentage } \\
\text { of dry } \\
\text { matter) }\end{array}$ & $\begin{array}{l}\text { Acetic } \\
\text { acid } \\
(\%)\end{array}$ & $\begin{array}{c}\text { Propionic } \\
\text { acid } \\
(\%)\end{array}$ & $\begin{array}{l}\text { Isobutyric } \\
\text { acid } \\
(\%)\end{array}$ & $\begin{array}{c}\text { Butyric } \\
\text { acid } \\
(\%)\end{array}$ & $\begin{array}{c}\text { Isovaleric } \\
\text { acid } \\
(\%)\end{array}$ & $\begin{array}{c}\text { Valeric } \\
\text { acid } \\
(\%)\end{array}$ \\
\hline I & 7 & $5^{\cdot 6}$ & $66 \cdot 2$ & $17 \cdot 6$ & $3 \cdot 2$ & 7.0 & $3 \cdot 6$ & $2 \cdot 2$ \\
\hline 2 & 3 & I $3 \cdot 6$ & 60.3 & $17 \cdot 6$ & $2 \cdot 3$ & 122 & $3 \cdot 2$ & $4 \cdot 5$ \\
\hline I & I & 4.5 & $78 \cdot 1$ & 10.2 & $2 \cdot 4$ & $5 \cdot 8$ & $2 \cdot 6$ & 0.9 \\
\hline 2 & I & $20 \cdot 1$ & $57^{\circ} \mathrm{I}$ & 12.4 & $1 \cdot 3$ & 19.4 & 2.4 & $5 \cdot 3$ \\
\hline
\end{tabular}

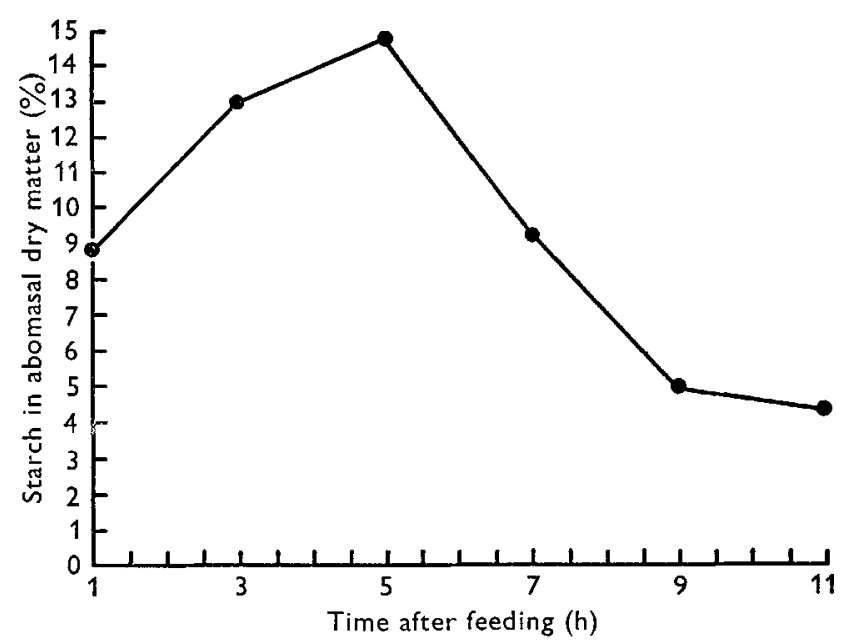

Fig. I. Influence of time of feeding on the concentration of starch in the dry matter of abomasal contents of lambs. Means of three consecutive measurements on one lamb receiving a rolled barley ration.

percentage of dietary starch reaching the abomasum were more than twice as great when rations consisting mainly of ground maize (GM) or cracked maize (CM) were given as they were when rolled barley (RB), flaked maize (FM) or any of the rations in Expt I were given. On two occasions about 25\% apparently escaped rumen fermentation when the CM ration was given. With all treatments the percentage of starch in faecal dry matter was higher than was recorded in Expt $\mathrm{r}$. However, the mean values never exceeded $\mathrm{I} \%$ of the dietary intake. Although there were no significant differences between diets, the highest value, $4 \%$ of starch in faecal dry matter, was recorded in an animal receiving the $\mathrm{CM}$ diet.

In Table 5 the proportions of VFA in samples of caecal digesta are given. The mean values obtained with all the barley-rich rations of Expt I have been compared with the means of those obtained with the three maize rations of Expt 2. The mean 
values for starch in samples of abomasal contents taken on the same day are also shown. The proportion of acetic acid tended to decrease as the percentage of starch in the abomasum increased; this relationship was clearest when the extremes of acetic acid proportions were compared.

To see if there was a diurnal variation in the percentage of starch in the abomasal dry matter, one sheep receiving diet RB was sampled over 2 consecutive days and I night and each sample analysed. The values are plotted in Fig. I. This shows clearly that the percentage of starch in abomasal dry matter rose to peak values $5^{-6} \mathrm{~h}$ after feeding and fell to the lowest values just before the next feed.

\section{DISCUSSION}

Though growth rates determined over periods of I I days are of limited value, they showed that the appetite and growth of the fistulated lambs were normal and similar to those of unfistulated lambs receiving similar rations (unpublished results). This would suggest that the surgical interference did not adversely influence the course of digestion.

From the results of Expt I it was apparent that the level of feeding influenced the proportion of starch which escaped rumen fermentation. This is in agreement with the results of Tucker et al. (1968) with sheep and also with trends observed in a fermentation balance approach with dairy cattle (Ørskov et al. 1968), but it does not agree with the recent findings of Topps et al. (1968) who observed no clear difference in the amounts of starch reaching the abomasum when pelleted barley rations were given to young steers at two levels of intake. The difference between species, or the fact that their results were based on observations from only two animals, might well explain the differences in results. The increase in the percentage of dietary starch reaching the abomasum when chopped dried grass was included in the ration was surprising; possibly the dried grass accelerated the rate of passage of the smaller particles out of the reticulo-rumen.

It is apparent also that the capacity of the small intestine to digest starch is limited. This is in accord with the finding of Walker (1959), that amylase secretion by the lamb is extremely low in comparison with that of the pig, and with the findings of Huber, Jacobson, McGilliard \& Allen (196r), who observed only small increases in blood sugar after administering starch to the abomasum of calves.

Though the results of Expt I are similar to those reported by Tucker et al. (1968) in that the percentage of starch in abomasal dry matter increased with dietary intake, the amounts we found escaping fermentation were relatively small in comparison with that reported by these workers. This discrepancy led us to investigate the effect of the nature of the starch used, since maize had been used by the American workers, whereas in Expt I we used barley. The results of Expt 2 showed clearly that the starch from ground or cracked maize was fermented in the rumen to a lesser extent than that from barley or flaked maize. It is possible that starch in raw maize is less accessible than that in flaked maize (which is steamed) or barley, since raw maize, unlike barley, contains a horny portion in the endosperm (Kerr, 1950), which might well reduce the 
rate of breakdown by the rumen micro-organisms. Whereas about $14 \%$ of dietary starch escaped fermentation from cracked maize in our work, about $38 \%$ escaped fermentation in the steers studied by Tucker $e t$ al. (1968). There were two occasions when our lambs reached values of $25 \%$, and it is possible that the difference in the mean values may have been affected by differences in analytical techniques. Besides this, the method we used for starch estimation was specific for $\alpha$-linked glucose polymers; the method used by Tucker $e t$ al. was not.

From the results given in Table 5, it is apparent that the type of caecal fermentation is influenced by a starchy substrate very much as rumen fermentation is influenced. It is well known that diets rich in starch tend to decrease the molar proportion of acetic acid in the rumen contents and increase the proportion of propionic or butyric acid. Though the animals with cannulas in the caecum did not have cannulas in the ileum, the results suggest that appreciable quantities of starch became available for fermentation in the caecum when the concentration of starch in the abomasal contents was increased. In Expt 2 such high concentrations of starch were associated with a depression in the molar proportion of acetate in the caecum and an increased proportion of butyrate. The extremely low concentrations of starch detected in the faeces showed that starch passing the lower ileum was effectively removed during fermentation in the caecum and large intestine. The high value of $4 \%$ found on one occasion may indicate that situations may well arise, particularly with maize diets and high levels of feeding, when undegraded starch will appear in the faeces in appreciable amounts.

In calculating the fraction of dietary starch reaching the abomasum, ileum and faeces from the ratio of starch or dry matter to PEG, it was assumed that no PEG was being degraded or absorbed during the passage through the gut. No attempt was made to check this assumption but the values for the digestibility of dry matter, which we have observed using this method, were similar to those which we found with similar rations and with total collection of faeces. Collection of faeces with rolled barley diets has shown the total digestibility of dry matter to be $77 \%$, whereas the mean digestibility observed here was $73 \%$.

The results illustrated in Fig. I, although based on three consecutive observations on one animal, indicate that frequent sampling is necessary to obtain reliable results and also illustrate that caution must be applied in interpreting similar results obtained from slaughter values unless time of feeding is taken into account.

An increase in the fraction of dietary carbohydrate that is digested and absorbed in the small intestine of ruminants is likely to increase the efficiency of utilization of that fraction. This is so, firstly, because fermentation losses, as methane and heat, would be avoided which, with fermented carbohydrate from concentrate, would probably amount to about $20 \%$ of the energy (Ørskov et al. I968), and secondly, because glucose infused into the abomasum of sheep (Armstrong, Blaxter \& Graham, I960) was apparently utilized more efficiently than fermentation end-products such as propionic acid (Armstrong \& Blaxter, 1957).

The influence of the absorption of digestible carbohydrate in the lower digestive tract on the availability of protein to the ruminant is more difficult to assess. Microbial 
protein formed in the rumen is an important source of the protein digested in the small intestine, and it might be assumed that, when nitrogen availability is not a limiting factor, the amount of microbial protein synthesized is related to the amount of carbohydrate fermented in the rumen. Consequently the microbial protein formed may be decreased when starch escapes fermentation and this will decrease the amount of protein passing to the intestines unless dietary protein is escaping fermentation at an equal rate. Hungate ( 1966 ) suggested that about $\mathrm{i} 2 \mathrm{~g}$ of microbial protein could be formed per $100 \mathrm{~g}$ organic matter fermented. Similar results were obtained recently by Hogan \& Weston (1967), and Ørskov et al. (1968) showed with a fermentation balance approach that the heat of fermentation was constantly related to the carbohydrate fermented regardless of type of fermentation, namely $6.4 \%$ of energy in the fermented material. A change in site of fermentation from the rumen to the caecum and large intestine is not likely to yield protein to the animal except with animals practising coprophagy, since little or no absorption of amino acids from the large intestine has been demonstrated.

The authors greatly appreciate the suggestions and help received from $\mathrm{Mr}$. McDonald in the design of the experiments and statistical treatment of the results. We also thank Mr A. Birnie for technical assistance, Mr R. S. Reid for the analysis of volatile fatty acids and $\mathrm{Mr} \mathrm{J}$. Hamilton for his care of the experimental animals.

\section{REFERENCES}

Agricultural Research Council (1965). The Nutrient Requirements of Farm Livestock. No, 2. Ruminants. London: H.M. Stationery Office.

Armstrong, D. G. \& Blaxter, K. L. (1957). Br. F. Nutr. Ix, 413.

Armstrong, D. G., Blaxter, K. L. \& Graham, N. McC. (1960). Proc. Nutr. Soc. r9, xxxi.

Heald, P. J. (1951). Br. F. Nutr. 5, 84.

Hogan, J. P. \& Weston, R. H. (1967). Aust. F. agric. Res, I8, 973.

Huber, J. T., Jacobson, N. L., McGilliard, A. D. \& Allen, R. S. (I961). F. Dairy Sci. 44, 32 I.

Hungate, R. E. (1966). The Rumen and its Microbes. New York and London: Academic Press Inc. Hydén, S. (1955). K. LantbrHögsk. Annlr 22, 139.

Karr, M. R., Little, C. O. \& Mitchell, G. E. (r966). F. Anim. Sci, 25, 652.

Kerr, R. W. (1950). Chemistry and Industry of Starch. New York and London: Academic Press Inc. MacRae, J. C. \& Armstrong, D. G. (1968). F. Sci. Fd Agric. 19, 578.

Orskov, E. R., Flatt, W. P. \& Moe, P. W. (1968). F. Dairy Sci. 51, I429.

Orskov, E. R. \& Fraser, C. (I968). Proc. Nutr. Soc. 27, 37 A.

Smith, R. H. (1958), Nature, Lond. 182, 260.

Topps, J. H., Kay, R. N. B. \& Goodall, E. D. (r968). Br. F. Nutr. 22, 26 I.

Topps, J. H., Kay, R. N. B., Goodall, E. D., Whitelaw, F. G. \& Reid, R. S. (I 968). Br. Y. Nutr. 22, 28 г.

Tucker, R. E., Mitchell, G. E. \& Little, C. O. (I968). F. Anim. Sci. 27, 824 .

Van Soest, P. J. (1963). F. Ass. off. agric. Chem. 46, 829.

Walker, D. M. (1959). F. agric Sci., Camb. 53, 374.

Weller, R. A. \& Gray, F. V. (1954). F. exp. Biol. 3r, 4 o.

Wright, P. L., Grainger, R. B. \& Marco, G. R. (1966). F. Nutr. 89, 241 . 